\title{
Indoor Microclimate of Buildings
}

\section{Mikroklima interiéru budov}

\section{Lucie Holopírková}

Ústav stavitelství, Fakulta architektury, Vysoké učení technické v Brně školitel: doc. Ing. Miloslav Meixner, CSc.

\begin{abstract}
One of the main priorities of our society is to constantly increase the quality of life. Part of new trends and technology is the optimizing of all factors affecting every individual in buildings functioning as homes, and working environments. During the creation of the architectural design for a building, we can greatly influence the microclimate of the building by suitably selecting material surfaces, using different ventilation systems and selecting structures that can affect the Earth's natural electromagnetic field. Ionic microclimate may be an indicator of a healthy environment and has a major impact on human health and psychological well-being.
\end{abstract}

KEYWORDS: microclimate; indoor climate of buildings; electro-ionic microclimate; negative ions; ionization of air; well-being and human health; air conditioning

\begin{abstract}
ABSTRAKT: JJednou ze základních priorit naší společnosti je stálé zvyšování kvality života. Součástí nových trendů a technologií je snaha o optimalizaci všech faktorů působících na každého jednotlivce v budovách, at už se jedná o domov, či pracovní prostředí. Již při architektonickém návrhu budovy je možné mikroklima budovy značně ovlivnit vhodným výběrem použitých materiálů povrchů, způsobem větrání a také výběrem konstrukcí, které ovlivňují přirozené elektromagnetické pole Země. Iontové mikroklima může být indikátorem zdravého prostředí a mít zásadní vliv na zdraví a psychickou pohodu člověka.
\end{abstract}

KLÍČOVÁ SLOVA: mikroklima; vnitřní prostředí budov; elektroiontové mikroklima; záporné ionty; ionizace vzduchu; pohoda a zdraví člověka; klimatizace 


\section{Úvod}

V interiéru se vyskytuje řada faktorů, které působí na člověka a které lze souhrnně definovat jako vnitřní mikroklima budov. Optimální úroveň těchto složek vytváří „stav pohody“. Podle definice WHO (World Health Organisation - WHO) je zdraví stav kompletní fyzické, mentální a sociální pohody, a nikoli pouze absence nemoci nebo slabosti.[1] Všechny tři stránky zdraví - fyzická, mentální a sociální - přitom musí být harmonicky sladěny.[2] Jak tedy můžeme této pohody dosáhnout? Jak ji můžeme změřit, př́ípadně co ji ohrožuje a jakým ohrožujícím faktorům můžeme čelit?

\section{Mikroklima v budově}

Mikroklima je podnebí malých prostor nebo malé oblasti. Je to soubor fyzikálních faktorů ovlivňující stav pracovního a obytného prostředí ve vymezeném prostoru. Parametry mikroklimatu určují subjektivní pocit komfortu, pohody a nepohody obyvatel. Mikroklima je část prostředí tvořená složkami, na jejichž přenosu se podílí vzduch.

Vzduch je do budovy přiváděn přirozeně, větráním okny nebo vhodně umístěným systémem průduchů, nebo uměle klimatizací. Jsou místnosti a budovy, které nelze větrat přirozeně, nebot to nedovoluje koncept budovy, např́klad u pasivních a nulových domů. Zde je pro kvalitu vnitřního mikroklimatu důležitý mechanický př́sun čerstvého vzduchu.

Vnitřní mikroklima jsou složky vnitřního prostředí, které jsou dány určitými principy a popsány vybranými fyzikálními a chemickými hodnotami. Dodržení limitů definovaných pro tyto hodnoty je podmínkou funkčnosti budovy a vytvoření zdravého prostředí pro člověka, jeho práci i odpočinek. Jedná se o celý soubor fyzikálních, chemických a biologických faktorů: tepelně-vlhkostní podmínky, koncentrace $\mathrm{CO}_{2}$, proudění vzduchu, prašnost, osvětlení, hluk, vibrace, elektrická a elektromagnetická pole, koncentrace toxických látek v ovzduší, kontaminace mikroby a plísněmi. Většinu těchto faktorů dokážeme ovlivnit větráním vnitřních prostor. Požadavky na větrání uzavřených prostor jsou dány stavebním zákonem a liší se v závislosti na činnosti člověka v budově.

Druhy mikroklimatu jsou tepelně-vlhkostní, odérové, toxické, aerosolové, mikrobiální, ionizující, elektrostatické, elektroiontové, elektromagnetické, akustické, psychické a světelné.[2] V tomto článku jsem se zaměřila na elektroiontové mikroklima jako důležitou složku vzduchu. 


\section{Elektroiontové mikroklima}

Stav elektroiontového mikroklimatu je jinými slovy koncentrace záporně a kladně nabitých iontů ve vzduchu. Elektricky neutrální ovzduší se v př́írodě vůbec nevyskytuje. Pro pocit komfortu v prostředí je určitý počet atmosférických iontů nezbytný. Studie a měření prokazují, že na člověka, všechny organismy a živé buňky mají pozitivní účinek záporné ionty. Kladné ionty, mají naopak účinek negativní.[4]

Vznik iontů: Proces ionizace nastává vytržením elektronu z atomu. Molekula vzduchu se díky působení energie rozštěpí na kladný a záporný elektron. Spojením záporně nabitého elektronu a molekuly vzduchu vznikne záporný iont. Záporné ionty tvoří shluky o 10-30 plynných molekulách, navázaných na elektricky nabitou částici a nesoucích její elektrický náboj (obr. 1). Celý tento proces trvá zlomek vteřiny a v atmosféře a v př́ŕodě probíhá neprètržitě.

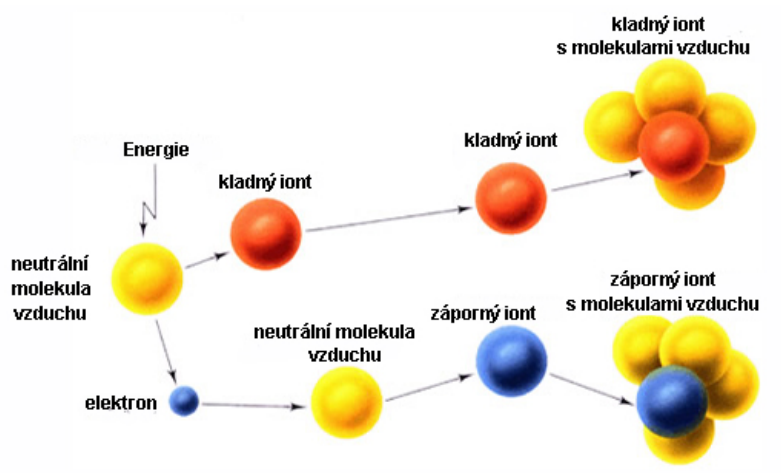

Obr. 1. Vznik záporných iontů v ovzduší. (Zdroj: Stavba Speciá, Zdravé klima: Záporné ionty hrají kladnou roli, Lajčíková Adriana)

Přirozený vznik iontů: Elektromagnetickým zářením, kosmickým zářením, slunečním zářením. Gama-zářením radioaktivních látek a minerálů obsažených přirozeně $\mathrm{v}$ zemské kủře (radon). Lénardovým efektem - vznik záporných iontů při prudkém dopadu částic vody na překážku nebo při rozprašování vody např́íklad ve vodopádech. Vzdušné ionty pak dělíme podle velikosti na lehké, střední a těžké. Organismům a člověku jsou prospěšné lehké záporné ionty, které vytvář́ shluky (iontová pole) a jejichž životnost je 10-30 sekund.

Uměle generované ionty: Organismu prospěšné záporné ionty můžeme vyrobit ionizátorem. Ionizátory pracují na principu koronového výboje či radiačního záření 
nebo využívají princip Lénardova efektu. Ionizátory jsou často spojovány s čističkou vzduchu nebo difuzérem. Záporné ionty produkované ionizátorem $\mathrm{k}$ sobě přitahují opačně nabité částice nečistot a prachu, které se shlukují a následně klesají k zemi jako prach, nebo jsou rekombinovány na okolních površích. Největší koncentrace záporných iontů se drží v blízkosti zdroje ionizování (1-2 metry). Vzhledem k rychlému zániku těchto částic vzduchu je pak nutné ionizovat nepřetržitě. Jakmile se generátor iontů vypne, hladina záporných iontů ve vzduchu v ionizovaném prostoru klesá a do hodiny se vrátí k původní hodnotě. Umělé ionizování lze využít pro dočasné zlepšení elektroiontového mikroklimatu v interiéru budov.

Způsoby měření vzdušných iontů: Ke stanovení koncentrací vzdušných iontů jsou užíány čítače iontů, tzv. iontometry, s jejichž pomocí lze stanovit počet iontů na $\mathrm{cm}^{3}$ vzduchu. Existuje několik typů měřičů koncentrace iontů, např́iklad deskový kondenzátor či aspirační válcový kondenzátor.

Požadované hodnoty: V normách nejsou uvedeny optimální a minimální hodnoty koncentrace lehkých záporných iontů v budovách, ale uvádí se v nich pouze doporučené hodnoty. Jako minimální počet lehkých záporných iontů se uvádí 50-250 iontů/ $\mathrm{cm}^{3}$ a jako optimální počet $250-1250$ iontů/ $\mathrm{cm}^{3}$. Počet lehkých negativních iontů/ $\mathrm{cm}^{3} \mathrm{v}$ prrírodě: u moře $1000-5000$, na horách $5000-30000, \mathrm{v}$ jeskynních prostorech $5000-50000$, v blízkosti vodopádů $10000-50000$ a po bouřce i více. Oproti tomu na ulici velkoměsta je to $100-500$, v místnosti městského bytu $50-100$ a v klimatizované místnosti 0-100 lehkých negativních iontů $/ \mathrm{cm}^{3}$.

Vliv iontů na člověka: Lékařské studie prokázaly, že lehké vzdušné ionty působí příznivě na fyzické i duševní zdraví, zvyšují mentální i fyzické schopnosti, mají specifické léčebné účinky, činí vzduch dýchatelnějším, lehčím a př́ijemnějším. Snahou je zajistit, aby se koncentrace iontů v pobytových prostorech co nejvíce přiblížila hodnotám koncentrace $\mathrm{v}$ neznečištěném přírodním prostředí. Vysoké koncentrace záporných iontů $\mathrm{v}$ jeskynních prostorech se využívá $\mathrm{k}$ léčbě astmatu, např́iklad v Dětské léčebně se speleoterapií v Ostrově u Macochy a v Sanatoriu Edel u Zlaté Hory.

Materiály a povrchy: Stavební konstrukce budov značně ovlivňují elektrické pole uvnitř staveb. Konstrukce $\mathrm{z}$ prŕrodních materiálů, např́klad z pálené cihly, dřeva, hlíny či slámy, minimálně deformují přirozené elektrické pole Země. V interiéru jsou ve vztahu k elektroiontovému mikroklimatu nejpříznivější: kámen, hlína pálená i nepálená, vápno a obecně př́rodní materiály bez chemických aditiv. PVC a syntetické materiály přitahují záporně nabité částice a ty zanikají.

Vliv na úroveň záporných iontů: Nízká úroveň lehkých záporných iontů je ovlivněna: vnitřním / vnějším znečištěním vzduchu, elektrostatickými poli, prachem, 
kouřem, vzduchotechnikou. Vysoká úroveň lehkých záporných iontů je ovlivněna: čistotou vnitřního a vnějšího vzduchu, radonem / zářením gama, otevřeným ohněm, velkými fontánami, sluncem, UV zářením. Počet lehkých iontů v ovzduší je tedy ukazatelem čistoty vzduchu.[5]

\section{Větrání a přívod čerstvého vzduchu}

„Spuštěním klimatizace koncentrace aeroiontů rychle klesá. Jestliže je vzduch veden $2 \mathrm{~m}$ dlouhým plechovým vzduchovodem o průmèru $10 \mathrm{~cm}$ rychlostí $1,5 \mathrm{~m} / \mathrm{s}$, vodivost vzduchu a koncentrace iontů klesá o $20 \%$."[2]

Z průzkumů ve velkých administrativních budovách, kde je klimatizace hlavním zdrojem čerstvého vzduchu, bylo uveřejněno, že se spuštěním klimatizačních jednotek se zvyšuje počet stížností pracovníků. Respondenti si stěžují na obavy z chladu, podrážděnost, únavu, bolesti hlavy, otupělost, ospalost. Vzduchotechnika a regulace vnitřního vzduchu jsou dnes nedílnou součástí standardů vybavení staveb, u administrativních budov a u velkých komplexů jsou naprosto nezbytné, ale jsou také součástí pasivních a nízkoenergetických rodinných domů. Ve vyhlášce je uvedeno, že vzduchotechnické zařízení musí zajistit parametry vnitřního ovzduší větraných prostorů vyhovující hygienickým a technologickým požadavkům. Jeho provoz musí být bezpečný a hospodárný, nesmí ohrožovat životní prostředí a zdraví osob nebo zviŕăat a musí umožňovat požadované pravidelné čištění a údržbu.[6] Za nejlevnější způsob, jak snížit spotřebu energie, se u mnoha stavbeb považuje minimální větrání. Ale bez ohledu na škodlivé plyny přítomné v moderních budovách se za to platí zdravím. Nepropustnost materiálů a hermeticky uzavřené domy umožňují hromadění polutantů uvolňujících se z materiálů, ale i produkovaných lidmi.[7][3] Jako př́iklad lze uvést oxid uhličitý v uzavřených prostorech - je prokázáno, že zvýšená hladina $\mathrm{CO}_{2}$ způsobuje sníženou pozornost, letargii, ospalost a bolest hlavy. „Za pomoci řízeného větrání by se u tohoto domu dalo dosáhnout i parametrů pasivní výstavby, ale my jsme na to záměrně rezignovali. Kladli jsme totiž dưraz na jiné kvality - především na čerstvý vzduch se zápornými ionty, "vysvětluje architekt Hozman. Elektroiontové mikroklima domu je důležité pro tělesnou i duševní pohodu jeho obyvatel. Plasty a další syntetické materiály v budovách snižují koncentraci záporně nabitých iontů a vytvářejí dnes již známý syndrom nemocných budov.[8] Na kvalitu vnitřního prostředí má zásadní vliv větrání, na tom se shodují všechny normy a vyhlášky. Údržba a čištění VZT neznamenají jen výměnu filtrů, ale také důkladné a pravidelné čištění všech rozvodů. 


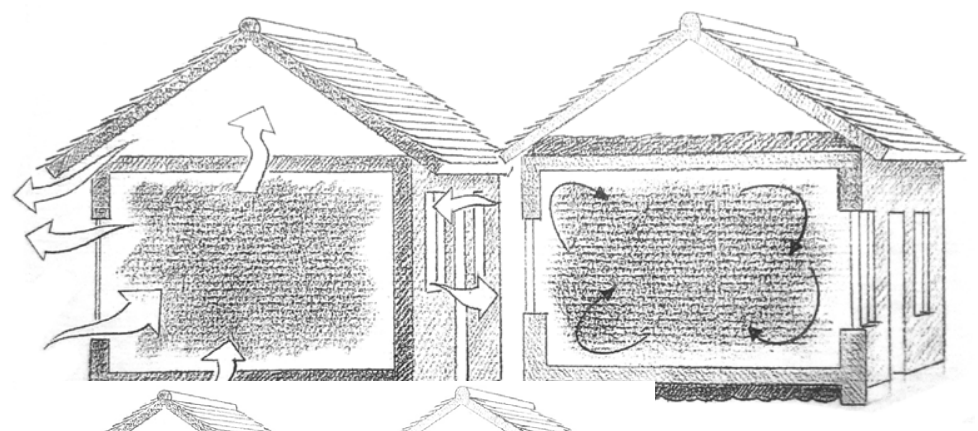

Obr. 2. Dům s propustnými nateriály a přirozeným systémem větráním vlevo, dům hermeticky uzavřen vpravo a hromadění znečištění vnitřního mikroklimatu. (Zdroj: PEARSON, David. Vivre au naturel. La maison écologique. Flamarion, 1999. $302 \mathrm{~s}$. ISBN: 2-08-201941-1)

\section{Měření koncentrace vzdušných iontů u výustí VZT}

\section{POROVNÁVACÍ MĚŘENÍ V NÍZKOENEGETICKÝCH DOMECH}

Porovnávací měření ve dvou nízkoenergetických domech s rekuperací tepla postavených na odlišných principech proběhlo roku 2013 v Praze a v Plzni. Měření byla provedena MUDr. Lajč́íkovou ze Státního zdravotního ústavu.

Popis staveb: Rodinný dům u Prahy je postaven z př́rodních materiálů, v místnosti, kde probíhalo měření, se nacházejí hliněné omítky a dřevěná podlaha s olejovým nátěrem. V rodinném domě u Plzně, kde probíhalo druhé měření, se nachází laminátová podlaha, v obývacím pokoji je umístěno kovové schodiště a na střeše je plechová krytina. Hodnoty jsou uvedeny v tabulce 1 .

\begin{tabular}{|l|c|}
\hline Dům v blizkosti PIzně & $(-)$ IONS/cm3 \\
\hline EXT-venkovní prostor & -400 \\
\hline INT-vnitřní prostor & $-30-50$ \\
\hline 10 min po spuštění rekuperace VZT & $-30-50$ \\
\hline V blízkosti rekuperace-chladný vzduch & -200 \\
\hline
\end{tabular}

\begin{tabular}{|l|c|}
\hline Dům v blízkosti Prahy & $(-)$ IONS/cm3 \\
\hline EXT-venkovni prostor & -350 \\
\hline INT-vnitřni prostor & -320 \\
\hline 10 min po spuštění rekuperace VZT & $-200-400$ \\
\hline V blízkosti rekuperace-horký vzduch & -70 \\
\hline
\end{tabular}

Tab. 1. Měření koncentrace záporných iontů v nízkoenergetických domechu Prahy a Plzně. Měřní provedla MUDr.Adriana Lajčíková, SZÚ.Ing.David Eyer:Zdravé bydlení. 2013. Dostupné z: http://cvut.mapovyportal.cz/OPPA_Eyer.pdf

Závěr měření: $Z$ naměřených hodnot je patrné, že vnitřní prostor domu z přírodních materiálů u Prahy vykazuje stejné koncentrace vzdušných záporných iontů jako v exteriéru, dům je tedy v souladu se svým prostředím. Při spuštění rekuperace s vede- 
ným teplým vzduchem hodnoty záporných iontů klesly, z výustí rekuperace vycházelo oproti vnitřnímu prostředí před spuštěním VZT malé množství záporných iontů. Dům u Plzně ze standardních materiálů fungoval opačně, ve vnitřním prostoru bylo naměřeno až desetkrát méně záporných iontů než v exteriéru. Po spuštění rekuperace s chladným vzduchem se nic nezměnilo, i když z výustí rekuperace proudil vzduch $\mathrm{s}$ vyšší koncentrací záporných iontů.

\section{MĚŘENÍ V NÍZKOENEGETICKÉ DŘEVOSTAVBĚ - TROJANOVICE}

13. 5 . 2016 bylo provedeno posouzení vnitřních mikroklimat v závislosti na řízené rekuperaci vzduchu v nízkoenergetické dřevostavbě firmy Př́rodní bydlení v Trojanovicích v Beskydech.

Popis stavby: Jedná se o nízkoenergetickou dřevostavbu (z 95 \% dřevěná), která je ve spodním patře využívána jako ateliér, dílna a sklad dřeva firmy Přírodní bydlení. Horní patro slouží jako prezentační místnost firmy s galerií různých druhů hliněných omítek a různých podlah z prrírodních materiálů a expozicí interiérového vybavení ze dřeva. Na této budově je odvětrávaná dřevěná fasáda z moravského modřínu bez venkovních nátěrů. Větrání a vytápění v horních místnostech jsou zajištěny rekuperační jednotkou, která byla dodatečně pořízena pro fungování administrativy v podkrovních místnostech.

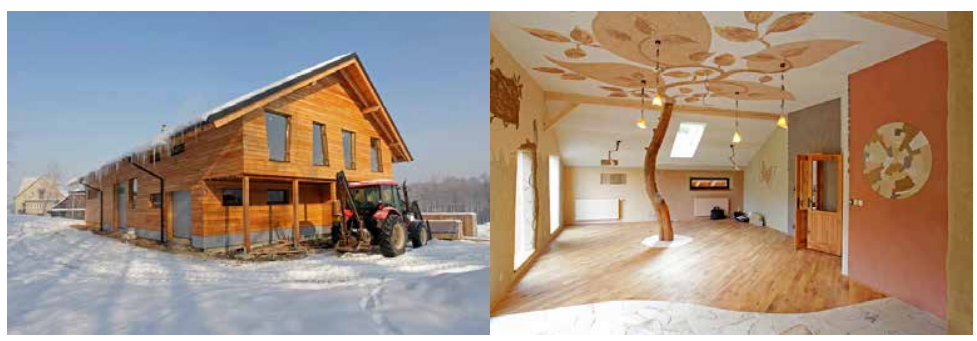

Obr. 3. Nízkoenergetická dřevostavba v Trojanovicích, exteriér a prezentační místnost, kde probíhalo měření vnitřního mikroklimatu. (Zdroj: http://www.prirodnibydleni.cz/ekostavby/drevostavby/)

Popis měření: Před měřením v interiéru bylo změřeno mikroklima v blízkosti budovy. Po příchodu do budovy bylo hned změřeno mikroklima interiéru uprostřed prezentační místnosti, přičemž byly naměřeny vysoké koncentrace záporných iontů. Dále byly zjištěny jejich velmi vysoké koncentrace o hodnotách až -1644 iontů/ $\mathrm{cm}^{3} \mathrm{v}$ blízkosti povrchu stěn $\mathrm{s}$ různými druhy hliněných omítek, $\mathrm{v}$ blízkosti podlahy z prŕrodního vápence pak koncentrace dosahovala až -1703 iontů $/ \mathrm{cm}^{3}$. Následně byla zapnuta rekuperace $\mathrm{v}$ módu chlazení, $\mathrm{z}$ výdechu rekuperace bylo naměřeno -189 
iontů $/ \mathrm{cm}^{3}$ a po 30 minutách chlazení byla naměřena hodnota -573 iontů $/ \mathrm{cm}^{3}$, což je o -367 iontů $/ \mathrm{cm}^{3}$ méně. Po vypnutí rekuperace se prostor nechal 2 hodiny přirozeně pracovat, vyvětralo se okny a následně se proměřily hodnoty. Ve středu místnosti bylo naměřeno -1222 iontů/ $\mathrm{cm}^{3}$, což je dvakrát více než s rekuperací, a u stěn a podlah kolem -900 iontů $/ \mathrm{cm}^{3}$, což je méně než před použitím rekuperace. Naměřené hodnoty jsou uvedeny v tabulce 2 .

Závěr měření: $Z$ naměřených hodnot je patrné, že výměnou vzduchu v místnosti pomocí rekuperační jednotky se přivádí vzduch s omezeným počtem záporných iontů. $\mathrm{V}$ exteriéru byla naměřena menší hodnota koncentrace záporných iontů než v interiéru s př́rodními materiály. Na základě výsledků se dále nabízí vysvětlení, že stěny $s$ hliněnými povrchy a přirodní kámen jsou schopné generovat prospěšné záporné ionty a postupně je pak uvolňovat do prostoru.

\begin{tabular}{|c|c|c|c|c|c|c|c|c|}
\hline čas & misto měření & způsob větrání & povrchy & $\begin{array}{l}(-) \text { IONS } \\
/ \mathrm{cm}^{3}\end{array}$ & \begin{tabular}{|l}
$(+)$ IONS \\
$/ \mathrm{cm}^{3}$
\end{tabular} & $\mathrm{TA} /{ }^{\circ} \mathrm{C}$ & $\mathrm{Rh}$ & $\begin{array}{l}\mathrm{CO}^{2} \\
\mathrm{ppm}\end{array}$ \\
\hline 9:50 & exteriér & přirozené u lesa & prírodní & -807 & 167 & 18 & $54 \%$ & 365 \\
\hline 10:30 & uprostřed m. & okny & prírodní & -940 & 78 & 25 & $35 \%$ & 744 \\
\hline 10:40 & v blízkosti podlahy & bez & př. kámen & -1703 & 500 & 27 & $31 \%$ & 503 \\
\hline 10:45 & v blizkosti stěn & bez & hliněné & -1644 & 633 & 27 & $27 \%$ & 669 \\
\hline 10:50 & & zapnuta rekuperace chlazení & & & & & & \\
\hline 11:00 & u vyústku rekuperace & rekuperace chlazení & PVC & -189 & 411 & 21 & $31 \%$ & 552 \\
\hline $11: 20$ & uprostřed mistnosti & rekuperace chlazení & prírodní & -573 & 442 & 26 & 33 & 433 \\
\hline 11:50 & & vypnuta rekuperace chlazení & & & & & & \\
\hline 13:50 & uprostřed mistnosti & bez & prírodní & -1222 & 300 & 25 & $33 \%$ & 667 \\
\hline 14:00 & $\mathrm{v}$ blízkosti podlah & rekuperace chlazeni & př. kámen & -907 & 558 & 25 & $33 \%$ & 602 \\
\hline $14: 20$ & v blízkosti stěn & rekuperace chlazení & hliněné & -922 & 542 & 26 & $33 \%$ & 635 \\
\hline
\end{tabular}

Tab. 2. Měření mikroklima interiéru v galerii přírodních materiálů v nízkoenergetické dřevostavbě, sídlo firmy Přírodní bydlení v Trojanovicích. 13.5.2016 Autor: Holopírková Lucie

\section{Shrnutí a závěry}

Na základě uvedených výsledků měření mohu konstatovat, že klimatizace a rekuperace vzduchu ovlivňují náboj a elektrické složení vzduchu přiváděného do budovy. $\mathrm{V}$ některých př́padech byl přiváděn vzduch bez elektrického náboje, bez záporných iontů, ten rekombinoval na stěnách potrubí přívodu vzduchu nebo na mřižzách výustí a nasávání vzduchu. Dále je zde otázka, jestli se nedají prŕvody vzduchu opatřit nátěrem nebo vyrobit z jiného materiálu, který nevybíjí elektrické částice vzduchu. Celá budova se všemi svými atributy, od architektonického návrhu a výběru materiálů až po technické vybavení, funguje jako celek, jako jeden organismus, který ovlivňuje mikroklima budovy, a to má následně vliv na zdraví a pohodu organismů a osob pohybujících se v těchto prostorech. Existují budovy a vnitřní prostory, které samy generují vzdušné záporné ionty a jsou schopné nepř́íznivou vlastnost umělé regulace vzduchu částečně eliminovat a zachovat příznivé elektrické mikroklima budovy. 


\section{Použitá literatura}

[1] Oficiální definice zdraví na stránkách Světové zdravotnické organizace / World Health Organisation: definition of health. [online]. [cit. 2018-07-05]. Dostupné z: http://www.who.int/suggestions/faq/en/

[2] JOKL, Miloslav. Zdravé obytné a pracovní prostředí. Vyd. 1. Praha: Academia, 2002. 261 s. ISBN: 80-200-0928-0

[3] PEARSON, David. Vivre au naturel. La maison écologique. Flamarion, 1999. 302 s. ISBN: 2-08-201941-1.

[4] JOKL, Miloslav. Mikroklima interiéru budov s různou materiálně-technickou základnou. Praha, 2009. Zdroj: https://docplayer.cz/3256876-Mikroklima-v-interieru-budov-s-ruznou-materialne-technickou-zakladnou-prof-ing-miloslav-jokl-drsc.html.

[5] LAJČÍKOVÁ, Adriana. Záporné ionty hrají kladnou roli. Stavba Speciál, Zdravé klima

[6] Vyhláška č.268/2009 Sb, \$37, Vzduchotechnická zařízení. [online:2017-10-19]. [cit. 2018-07-05]. Dostupné z: https://www.zakonyprolidi.cz/cs/2009-268\#cast5

[7] DAY, Christopher. Duch \& místo: Uzdravování našeho prostředí. Uzdravující prostředí. Brno: ERA, 2004, 126 s.

[8] Hozman, Oldřich. Hrázděné bydlení pro další generace. Můj dům, stavíme zařizujeme bydlíme. Studio AR. [online]. [cit. 2013-05-02]. Dostupné z: http://mujdum. dumabyt.cz/rubriky/stavba/hrazdene-bydleni-pro-dalsi-generace_105.html. 